\title{
Digitalization of Restaurant Business as a Factor of Competitiveness Increase
}

\author{
Pyanikova E.A.* \\ South-West state University \\ Kursk, Russia \\ e-mail: pyanikovaelvira@yandex.ru \\ Kovaleva A.E. \\ South-West state University \\ Kursk, Russia \\ e-mail: a.e.kovaleva@yandex.ru \\ Galchenko S.I. \\ South-West state University \\ Kursk, Russia \\ e-mail: svetagalchenko@yandex.ru
}

\author{
Kobchenko S.N. \\ Kursk state agricultural Academy named after I.I. Ivanov \\ Kursk, Russia \\ e-mail: 46cxa@mail.ru
}

\author{
Ovchinnikova E.V. \\ Belgorod University of Cooperation \\ Kursk, Russia \\ e-mail: e.ov4innikova2011@yandex.ru
}

\author{
Pikalova M.B. \\ South-West state University \\ Kursk, Russia \\ e-mail: tt-kstu@yandex.ru
}

\begin{abstract}
Since the emergence and spread of digital technologies, humanity has entered the era of digitalization. The impact of these technologies on socio-economic phenomena and processes in modern economic systems was so strong that it led to the transformation of the basic model of organization and development of these systems. By continuing to help optimizing economic activity in the restaurant industry, it can become a source of global prosperity if it is adopted and successfully implemented by all countries of the world. The research presented in the article is devoted to the application of digitalization in the field of public catering. The article reviews the ratings of regional catering companies on the American TripAdvisor website. It allows its users to plan their leisure time in any country of the world. The huge popularity of the site in Russia is due to its accessibility to users. This site uses the principle of "user content", that is, information content of media created by consumers. Reviews posted on an online portal (such as TripAdvisor) provide useful information to potential customers. As a result, the consumer can view the menu, make an order, or leave a review about any catering company via remote access. Reviews that are left there can affect consumer attitudes towards a product or service of a particular catering company, and as a result, the rating of the company itself. Most restaurant customers only want to write a review when they have strong positive or negative impressions. These impressions are most likely related to such factors as the quality of food, the level of service, and the price-quality ratio of the product. These indicators are the criteria for evaluating regional catering establishments on the TripAdvisor website. To automate the operation of the enterprise, it is proposed to introduce automation through the introduction of an electronic menu. Digitalization allows identifying and comparing the potential benefits of its implementation in the restaurant business.
\end{abstract}

Keywords - digitalization, catering companies, rating, service, food, price/quality.

\section{INTRODUCTION}

Currently, there is an increase in competition in all sectors of economy. The problem of attracting customers is also relevant for companies working in the field of public catering, the result of which is services.

Increased attention to the issue of attracting customers from these companies is connected, on the one hand, with the properties of the service as a product. The implementation of the service is inseparable from the production process itself. In this regard, the quality of the service is highly dependent on the psychological emotional state of the consumer, his/her expectations and on the work of the service personnel, their mood and behavior standards.

Digitalization of the service process in restaurants in terms of the introduction of electronic menus will eliminate the influence of the personal factor of the staff on the visitor.

The emergence of competition causes increased interest and special attention to the company's activities, to the development and implementation of digital technologies aimed at promoting the offered services, attracting and retaining customers, and improving the level of service [1].

The introduction and use of digital technologies in the restaurant business will have an impact:

- on the results of financial activities of public catering enterprises

- it will allow creating permanent customers.

Digital technologies are becoming an important marketing function and the key to commercial success. 
Digital technologies are the degree of perfection of the process of serving the population in psychological, ethical, aesthetic, organizational, technological and other aspects.

A key success factor is the ability to respond quickly and sensitively to the development of digital technologies and their application in various spheres of life, making the necessary internal and external changes [2].

When evaluating the possibility of developing the service sector, it is essential to analyze such a large component as public catering [3].

Catering is an integral part of the modern world, where visitors can quickly and deliciously eat home-style meals, and drink a cup of coffee for a moderate fee. Kursk city annually serves hundreds of thousands of guests and residents.

The development of the consumer market in the region under study has been in recent years characterized by a dynamic expansion of the industry's infrastructure and an increase in the quality of services provided.

As of 01.01.2019, 178 public catering enterprises were registered on the regional market.

The infrastructure of the consumer market is updated annually with new modern formats of public catering enterprises. These are fast food companies, cafes, and bars. Such type of service, as "meals on wheels", is widely used. Fast food, located in large shopping and entertainment centers and hypermarkets, is still a popular and affordable type of catering [4].

As a result of the economic reforms that have been carried out over the past $10-15$ years, Russia has changed its approach to managing many sectors, including the public catering one. Now the state as well as an individual can be the owner of a public catering organization. Such an organization in Kursk can work in a variety of organizational and legal forms. At the same time, it must be clearly understood that an entrepreneur in the field of public catering provides the same services for profit as in other areas of business, but at the same time a number of special mandatory conditions are imposed on his activities.

The purpose of the study is to assess the level of competitive advantages of services at public catering enterprises in the region using digital technologies.

To achieve this goal, it is necessary to solve the following tasks:

- to analyze and identify the most popular review site;

- to make an analysis of the region's catering establishments registered on the TripAdvisor website;

- to build a rating of food companies based on service indicators, to evaluate the possibility of using digital technologies in them;

- to analyze the use of digital technologies in foreign practice;

- to recommend the modern means of automation for implementation at the enterprises of public catering.

\section{METHODOLOGY}

To analyze the use of these information technologies, companies that occupy the top 20 positions among 178 restaurants in the regional ranking were selected.

Promising digital technologies in public catering are investigated on the basis of such methods as analysis, synthesis and generalization of assessments of available reviews, identifying and fixing the gap from the proposed conditions for digitalization and Informatization.

The study uses primary and secondary data, which can be used to estimate the Informatization of the restaurant business [5].

With the advent of the Internet and social networks, online reviews are becoming increasingly popular as an important source of information [6] that can influence product sales and profitability [7-9]. Thus, understanding the factors underlying the consumers' feedback behavior is important for business success and development [10].

The popularity of information resources allows consumers with different preferences to use the same site for their ratings [11].

In order to assess the current state of digital technology use in business, the authors analyzed the information provided on TripAdvisor. The estimation is made concerning the possibility to use digital technologies for further sample survey of Russian enterprises in the restaurant business, noncash payment through the electronic payment system, the availability of its own website and access to the Internet, the electronic booking system, the use of an electronic menu, an interactive table.

As the research shows, the system for evaluating restaurants on various sites is still poorly developed in the region. One can leave a review and evaluate the service activities of a restaurant, cafe, bar, club on Restoclab, Allcafe, Zoon, TripAdvisor, Restoran, Restaurant Guru.

When analyzing these sites, it has been found that TripAdvisor is in the first place in terms of the number of consumer visits per month with 23.5 million visits per month, and Zoon is in the second place with 10.7 million visits per month. Other sites have rates as following: Restoclab -720.7 thousand visits per month, Restoran - 395 thousand visits per month, Allcafe -160.9 thousand visits per month.

In the future, research will be conducted on TripAdvisor as the most popular American site in the region under study. The popularity of this site in Russia is connected with its accessibility to users. This service is free and uses the principle of "user content".

\section{RESULTS}

Digitalization of the restaurant business is inevitable. Technologies and automation of processes, as it turned out in recent years, allow people to multiply the traffic of institutions, increase profits and reduce losses.

No matter what digital technologies are invented for restaurants - the field for imagination is limitless, one can 
improve and optimize it indefinitely - restaurants should remain first of all a comfortable place, perhaps a little conservative, where people come not only to eat, but also to have a good time, relax and escape from the hustle and bustle. Digital technologies are needed to improve service, reduce costs, and make the life of restaurateurs more comfortable and simple.

The study examines the restaurant sector, which is mainly composed of independent small and medium-sized enterprises [12].

From the materials presented on the TripAdvisor website, a summary table was compiled 01 in the overall rating of "Top 20 best restaurants" in Kursk. The rating is based on the indicators of 2019 in comparison with 2018 according to the criteria "food", "service", "price/quality".

TABLE I. THE RATING OF THE BEST RESTAURANTS IN THE CITY OF KURSK, ACCORDING TO THE CRITERIA

\begin{tabular}{|c|c|c|c|c|c|c|c|c|c|}
\hline \multirow{2}{*}{$\begin{array}{l}\text { Name of the } \\
\text { restaurant }\end{array}$} & \multirow[b]{2}{*}{ 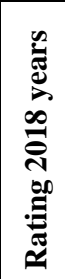 } & \multicolumn{3}{|c|}{ Indicators } & \multirow[b]{2}{*}{ 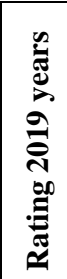 } & \multicolumn{4}{|c|}{ Indicators } \\
\hline & & $\begin{array}{c}3 \\
8 \\
8 \\
1\end{array}$ & : & 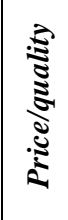 & & 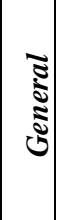 & $\overbrace{1}^{2}$ & 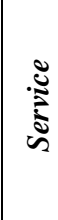 & 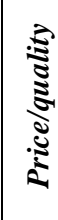 \\
\hline $\begin{array}{l}\text { Cafe-bar } \\
\text { "Amsterdam" }\end{array}$ & 7 & 4 & 4 & 4 & 1 & 4.5 & 4.5 & 4.5 & 4 \\
\hline $\begin{array}{l}\text { Restaurant } \\
\text { "Kotleta" }\end{array}$ & 2 & 4.5 & 4.5 & 4.5 & 2 & 4.5 & 4.5 & 4.5 & 4 \\
\hline $\begin{array}{l}\text { Restaurant } \\
\text { "Bykovsky" }\end{array}$ & 1 & 4 & 3.5 & 4 & 3 & 4.0 & 4.0 & 3.5 & 3.5 \\
\hline $\begin{array}{l}\text { Restaurant } \\
\text { "Aquamarine" }\end{array}$ & 4 & 4.5 & 4.5 & 4.5 & 4 & 4.5 & 4.5 & 4.5 & 4.5 \\
\hline $\begin{array}{l}\text { Cafe } \\
\text { "Fresh Cafe" }\end{array}$ & 9 & 4.5 & 4.5 & 4.5 & 5 & 4.5 & 4.5 & 4.0 & 4.5 \\
\hline $\begin{array}{l}\text { Restaurant } \\
\text { "Prestige" } \\
\end{array}$ & 5 & 4.5 & 4.5 & 4 & 6 & 4.5 & 4.5 & 4.5 & 4.0 \\
\hline Papa Pit & - & - & - & - & 7 & 4.5 & - & - & - \\
\hline $\begin{array}{l}\text { Restaurant } \\
\text { "Dikanka" }\end{array}$ & 3 & 4.5 & 4.5 & 4 & 8 & 4.0 & 4.5 & 4 & 4 \\
\hline $\begin{array}{l}\text { Restaurant } \\
\text { "Nevsky" }\end{array}$ & 8 & 5 & 5 & 4 & 9 & 4.5 & 5.0 & 5.0 & 4.0 \\
\hline $\begin{array}{l}\text { Restaurant } \\
\text { "Saasons" }\end{array}$ & - & - & - & - & 10 & 4.5 & 4.0 & 4.5 & 4.0 \\
\hline "Boulanger" & 14 & 4 & 4 & 4 & 11 & 4.0 & 4.0 & 4.0 & 4.0 \\
\hline $\begin{array}{l}\text { Cafe } \\
\text { "Pasta Basta" }\end{array}$ & 6 & 4.5 & 4.5 & 4.5 & 12 & 4.5 & 4.5 & 4.5 & 4.5 \\
\hline City cafe "SAVA" & 20 & 3.5 & 4 & 3.5 & 13 & 4.0 & 3.5 & 4.0 & 3.5 \\
\hline $\begin{array}{l}\text { Bar "BLACK } \\
\text { BEAR Bar } \\
\text { Boutique" }\end{array}$ & 18 & 4.5 & 5 & 4.5 & 14 & 4.5 & 4.5 & 4.5 & 4.5 \\
\hline $\begin{array}{l}\text { fast-food restaurant } \\
\text { chain } \\
\text { "Zhar pizza" }\end{array}$ & 13 & 3.5 & 4 & 4.5 & 15 & 4.0 & 3.5 & 4.0 & 4.5 \\
\hline $\begin{array}{l}\text { Barbecue bar } \\
\text { "Piratskaya pristan" }\end{array}$ & 11 & 4 & 4 & 4 & 16 & 3.5 & 4.0 & 4.0 & 4.0 \\
\hline $\begin{array}{l}\text { fast-food restaurant } \\
\text { chain "McDonalds" }\end{array}$ & 15 & 4 & 5 & 4 & 17 & 4.0 & 4.0 & 5.0 & 4.0 \\
\hline $\begin{array}{l}\text { Pub \& Shop The } \\
\text { Cock }\end{array}$ & - & - & - & - & 18 & 5.0 & - & - & - \\
\hline Cafe "Riviera" & 19 & 4 & 4.5 & 4 & 19 & 4.5 & 4.0 & 4.5 & 4.0 \\
\hline Cafe-bar "Pelican" & 16 & 5 & 5 & 5 & 20 & 4.5 & 5.0 & 5.0 & 5.0 \\
\hline
\end{tabular}

As it can be seen from table 01, the restaurant "Kotleta" has been consistently ranked 2 nd in the rating for two years, the restaurant "Aquamarine" has been ranked 4th, and the cafe "Riviera" has been ranked 19th. Some restaurants experienced a shift in their positions towards improvement. Thus, the "Amsterdam" cafe-bar took the 7th place in 2018, and in 2019 it rose by 6 positions. The rating change is related to the improvement of the "food" and "service" indicators (from 4 to 4.5). "Fresh Cafe" grew by 4 positions: 5th place in 2019. "Boulanger" cafe in 2019 rose by 3 positions and took the 11th place. "SAVA" city cafe in 2019 gained 7 positions and took the 13th place. The "BLACK BEAR bar Boutique" took the 14 th place in 2019 , rising to 4 positions.

Some restaurants have lowered their positions. In the "Bykovsky" restaurant, the rating dropped from 1 place to 3 . The rating was downgraded due to a reduction in the "price/quality" rating. This is due to the increase in prices for dishes. "Prestige" restaurant moved to 1 position (from 5) and in 2019 took the 6th place. "Dikanka" restaurant dropped 5 positions: from 3rd place in 2018 to 8th place in 2019. "Nevsky" restaurant moved from 8th position in 2018 to 9 th in 2019. "Pasta Basta" cafe dropped 6 positions from 6th place to 12th during the period under review. "Zhar Pizza" network fast food restaurant shifted from 13 to 15. "Piratskaya pristan" barbeque-bar shifted from 11 to 15 . "McDonalds" shifted from 15 to 17 .

In 2018, the top 20 restaurants in Kursk included such restaurants as "Mezzanine" (17th place), "Biblioteka" (10th place) and "Restoration" (12th place). In 2019, the restaurant "Mezzanine" lowered its position and took 24th place in the rating. The "Biblioteka" and "Restoration" restaurants closed in 2019.

In 2019, new catering establishments appeared in the ranking of 20 restaurants in Kursk: "Papa Pit" (7th place), "Saasons" (10th place) and "Pub \& Shop The Cock" (18th place).

When evaluating food companies: "Amsterdam", "Dikanka" and "Boulanger", consumers note such an indicator as the atmosphere in the restaurant hall. In all these institutions, it corresponds to 4 points.

During the study, a comparative analysis of the rating of the best restaurants in Kursk was made, that was based on customer reviews in 2018 [13] and in 2019 by points. Ratings of the best 20 restaurants in Kursk in 2019 are based on customer reviews is shown in table 02 .

On the TripAdvisor website, a visitor can leave a review and rate the catering company on the following scale: "excellent", "very good", "not bad", "bad", "terrible". The authors have translated this scale into a 5-point scale for ease of analysis: "excellent" - 5 points, "very good" -4 points, "not bad" - 3 points, "bad" -2 points, "terrible" -1 point. One can see from table 02 data that for a number of restaurants such as "Amsterdam", "Kotleta", "Bykovsky", "Dikanka", "SAVA", "Piratskaya pristan", the number of reviews on average increased from 20 to 40 in 2019 compared to 2018.

As it can be seen from the data presented, the number of reviews does not affect the place in the rating. Ratings in the 
review are of great importance. A restaurant that has "excellent" and "very good" ratings in the review rises in the rating. A restaurant whose reviews are rated "bad" and "terrible" is downgraded.

TABLE II. RATING OF THE BEST RESTAURANTS IN KURSK, BASED ON CUSTOMER REVIEWS

\begin{tabular}{|c|c|c|c|c|c|c|}
\hline \multirow{2}{*}{$\begin{array}{l}\text { Name of the } \\
\text { restaurant }\end{array}$} & \multirow{2}{*}{$\begin{array}{c}\text { Total } \\
\text { reviews }\end{array}$} & \multicolumn{5}{|c|}{ Number of reviews by rating } \\
\hline & & 5 & 4 & 3 & 2 & 1 \\
\hline Cafe-bar "Amsterdam" & 118 & 66 & 26 & 11 & 4 & 4 \\
\hline Restaurant "Kotleta" & 80 & 58 & 12 & 4 & 3 & 3 \\
\hline Restaurant "Bykovsky" & 164 & 81 & 36 & 22 & 11 & 10 \\
\hline $\begin{array}{l}\text { Restaurant } \\
\text { "Aquamarine" }\end{array}$ & 38 & 27 & 7 & 2 & 1 & 0 \\
\hline Cafe "Fresh Cafe" & 56 & 33 & 16 & 2 & 2 & 3 \\
\hline Restaurant "Prestige" & 54 & 31 & 13 & 6 & 2 & 1 \\
\hline Papa Pit & 30 & 25 & 2 & 1 & 0 & 2 \\
\hline Restaurant "Dikanka" & 104 & 54 & 19 & 15 & 10 & 5 \\
\hline Restaurant "Nevsky" & 44 & 31 & 7 & 2 & 1 & 2 \\
\hline Restaurant "Saasons" & 23 & 18 & 2 & 0 & 2 & 1 \\
\hline "Boulanger" & 96 & 40 & 31 & 8 & 9 & 7 \\
\hline Cafe "Pasta Basta" & 44 & 27 & 8 & 1 & 4 & 3 \\
\hline City cafe "SAVA" & 60 & 28 & 14 & 5 & 8 & 5 \\
\hline $\begin{array}{l}\text { Bar "BLACK BEAR Bar } \\
\text { Boutique" }\end{array}$ & 46 & 28 & 6 & 5 & 4 & 1 \\
\hline $\begin{array}{l}\text { fast-food restaurant } \\
\text { chain "Zhar pizza" }\end{array}$ & 35 & 9 & 16 & 7 & 2 & 0 \\
\hline $\begin{array}{l}\text { Barbecue bar "Piratskaya } \\
\text { pristan" }\end{array}$ & 112 & 43 & 30 & 13 & 8 & 17 \\
\hline $\begin{array}{l}\text { fast-food restaurant } \\
\text { chain "McDonalds" }\end{array}$ & 27 & 10 & 8 & 7 & 0 & 0 \\
\hline Pub \& Shop The Cock & 9 & 8 & 1 & 0 & 0 & 0 \\
\hline Cafe «Riviera» & 18 & 11 & 6 & 0 & 0 & 1 \\
\hline Cafe-bar "Pelican" & 27 & 21 & 3 & 1 & 0 & 2 \\
\hline
\end{tabular}

\section{CONCLUSION}

Catering companies need to pay more attention to the reviews that visitors leave. The more positive reviews there are, the higher the company's rating. To do this, restaurateurs need to leave links to TripAdvisor on the website of their food company, so that the customer can immediately leave a review about it while in the restaurant. Information from reviews should be analyzed in a timely manner. Thus, that all defects that arise are eliminated in a timely manner.

In the course of the research, 2 areas of implementation of digital technologies can be identified:

The first direction is the use of digitalization of the restaurant business through the interaction of enterprises with consumers and marketing;

The second direction is the introduction of automation through the introduction of electronic menus, touch-based selfservice terminals, mobile applications for restaurant retail, etc. [14].

The electronic menu of the restaurant is a tablet, thanks to which one can get comprehensive information about each meal: a photo of the finished dish, its price, the list of ingredients, calories, cooking time, and a detailed description of the cooking process. After making his/her choice, a visitor to a restaurant or cafe confirms their choice and the order is passed to the kitchen. The chefs start cooking. In this case, the influence of the personal factor of the service personnel on the visitor is excluded.

The electronic menu, as an automation system for restaurants, cafes, bars, will make the process of selecting dishes as simple and convenient as possible, and will allow keeping statistics of ordered dishes. Automated ordering will improve the quality of service, increase loyalty and the number of regular customers of the institution.

In our region, none of the catering companies use this technology. At the same time, a number of restaurants in Europe, the United States and Japan are experiencing a new technology for ordering dishes using touch screens, designed to replace not always polite and sometimes mistaken waiters. And this brings positive results: increased profits; simplicity and convenience when ordering and as a result - an increase in the number of dishes ordered; improved service quality; reduced time for accepting and processing orders; increased interest in service; the electronic menu will attract new customers who are curious about everything new; the convenience of updating the range and prices. To make changes to the menu, it is not necessary to re-print anything, just a couple of clicks.

Using the electronic menu, customers will not only be able to order food, but also listen to music and play games while waiting for an order. Music, games, chat, drawing for children, quizzes, horoscope, videos, jokes, useful tips will not only entertain visitors, but also help to make additional orders.

The study allows identifying what forms of informatization take place in regional Russian companies in the restaurant industry, and what are the interactions of restaurateurs with customers in this area.

Even today, it can be noted that those companies that use modern digital technologies and innovative strategies are competitive.

\section{References}

[1] E.A. Pyanikova, A.E. Kovaleva, E.I. Bykovskaya, "Digital technologies in public catering industry (regional aspect)", pp. 482-488, Atlantes press: Advances in Economics, Business and Management Research, vol. 81 [1st Int. Sci. Conf. Modern Management Trends and the Digita Economy: from Regional Development to Global Economic Growth (MTDE 2019)].

[2] N.A. Serebryakova, I.V. Avdeev, "The content of structural transformations of the region's economy, adequate to the requirements of digitalization", Proc. of the Voronezh State Univer. of Engineer. Technol., vol. 80, no. 4, pp. 408-412, 2018. Retrieved from: https://doi.org/10.20914/2310-1202-2018-4-408-412

[3] A.A. Gazhur, I.N. Lukiyanchuk, "Trends of development of the sphere of services in Russia”, Proc. of the Voronezh State Univer. of Engineer. Technol., vol. 80, no. 3, pp. 444-450, 2018. Retrieved from: https://doi.org/10.20914/2310-1202-2018-3-444-450

[4] S.F. Ryumshina, E.A. Pyanikova, "Theoretical aspects of determining the demand for food products and services", pp. 144-149, 2017 [Collection of scientific articles materials of the 3rd Int. sci. and pract. Conf. Food production Technology and product expertise, Responsible ed. A.A. Gorokhov].

[5] Ya.V. Batsyn, "Use and prospects of digital technologies in the restaurant business", Bull. of the Altai Acad. of Econ. and law, no. 4, part 1, pp. 10-18, 2019. DOI 1017513/vaael.399 
[6] H. Li, C.R. Wang, F. Meng, Z. Zhang, "Making restaurant reviews useful and/or enjoyable? The impacts of temporal, explanatory, and sensory cues", Int. J. of Hospitality Manag., vol. 83, pp. 257-265, October 2019. Retrieved from: https://doi.org/10.1016/j.ijhm. 2018.11.002

[7] J.A. Chevalier, D. Mayzlin, "The Effect of Word of Mouth on Sales: Online Book Reviews", J. of Market. Res., vol. 43, pp. 345-354. Retrieved from: https://doi.org/10.1509/jmkr.43.3.345

[8] Q. Ye, R. Law, B. Gu, "The Impact of Online User Reviews on Hotel Room Sales. International”, J. of Hospitality Manag., vol. 28, pp. 180-182. Retrieved from: https://doi.org/10.1016/j.ijhm.2008.06.011

[9] F. Zhu, X. Zhang, "Impact of online consumer reviews on sales Themoderating role of product and consumer characteristics", J. of Market., vol, 74, no. 2, pp. 133-148, 2010. DOI:10.1509/jmkg.74.2.133

[10] Li. Hengyun, L.X. Karen, Zh. Zili, "The effects of consumer experience and disconfirmation on the timingofonlinereview: Fieldevidence from the restaur ant business", Int. J. of Hospitality Manag., vol. 84, 102344,
January 2020. Retrieved from: https://doi.org/10.1016/j.ijhm. 2019.102344

[11] Makoto Nakayama, Yun Wan, "The cultural impact on social commerce: A sentiment analysis on Yelp ethnic restaurant reviews", Inform. \& Manag., vol. 56, iss. 2, pp. 271-279, March 2019. Retrieved from: https://doi.org/10.1016/j.im.2018.09.004Get rights and content.

[12] A. Akbaba, "Business performance of small tourism enterprises: A comparison among three sub-sectors of the industry Anatolia", Int. J. of Tourism and Hospitality Res., vol. 23, pp. 177-195, 2012.

[13] I.V. Minakova, E.A. Pyannikova, E.I. Bykovskaya, A.E. Kovaleva, "Improving the quality of service in public catering establishments based on the use of multi-stage evaluation systems", Bull. of the Altai Acad. of Econ. and law, no. 5-2, pp. 71-76, 2019.

[14] D.H. Song, C.Y. Son, "Comparing the public sphere in social networking services during a period of political upheaval: The three news channels' Facebook accounts in the 2016 South Korean Presidential scandal", Int. J. of Digital Television, vol. 8, no. 3, pp. 351-366, 2017. 